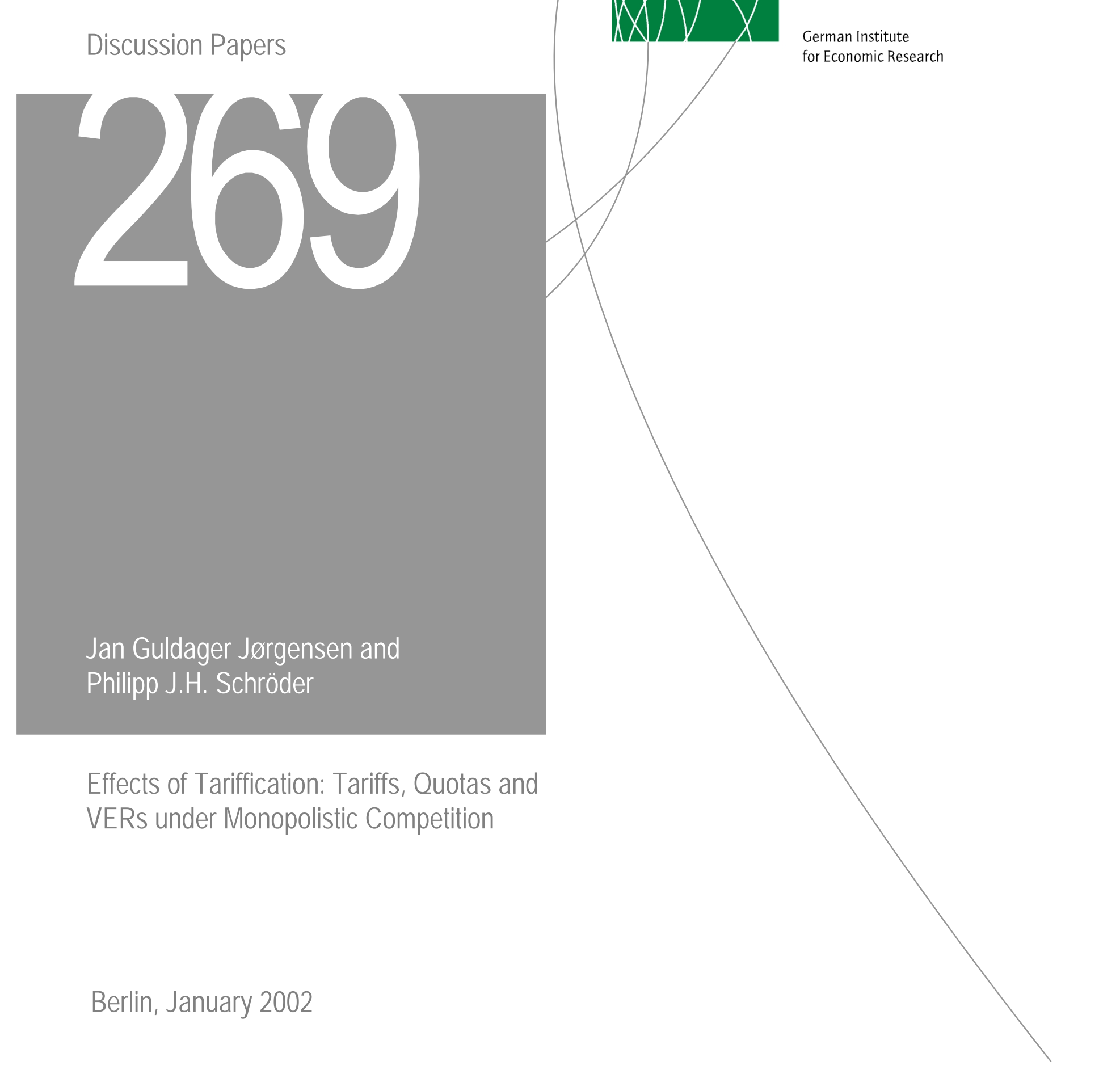


Opinions expressed in this paper are those of the author and do not necessarily reflect views of the Institute.

\section{DIW Berlin}

German Institute

for Economic Research

Königin-Luise-Str. 5

14195 Berlin,

Germany

Phone $+49-30-89789-0$

Fax +49-30-897 89-200

www.diw.de

ISSN 1619-4535 


\title{
Effects of Tariffication: \\ Tariffs, Quotas and VERs under Monopolistic Competition
}

\author{
Jan Guldager Jørgensen ${ }^{a}$ \\ and \\ Philipp J.H. Schröder ${ }^{\mathrm{b}, 1}$ \\ ${ }^{a}$ University of Southern Denmark, Department of Economics, Denmark \\ ${ }^{\mathrm{b}}$ DIW - German Institute for Economic Research, Berlin, Germany
}

\begin{abstract}
Recent rounds of GATT and later WTO have advocated widespread tariffication, meaning that existing non-tariff barriers be converted into import equivalent tariffs. From an economic point of view, the effects of such tariffication are not entirely clear. The paper presents a general equilibrium model with monopolistic competition to examine the welfare effects of tariffication. The ranking of pre- and post-tariffication welfare depends crucially on the nature of the initial trade barrier and the tariff tool applied. Tariffication using a specific (an ad valorem) tariff results in the same (a reduced) welfare level compared to an initial quota, whereas welfare is increased (the same) compared to an initial VER.
\end{abstract}

Key Words: Trade policy, tariffication, specific tariff, ad valorem tariff, quota, VER. JEL: F02, F12, F13

1. Corresponding author. DIW Berlin, The German Institute for Economic Research, Königin-Luise-Str.5, 14195 Berlin, Germany, Tel.: +49 30897 89692, Fax: + 4930897 89108, e-mail: pschroeder@diw.de 


\section{Introduction}

In the past ten years tariffication - the conversion of non-tariff barriers such as quotas and voluntary export restraints (VERs) into import-equivalent tariffs - has been promoted and implemented on a global scale. Yet, the welfare effects of such policies have not been fully understood. The present paper addresses this issue for the case where industries feature monopolistic competition. In particular the paper finds that, in terms of consumers' utility, tariffication using a specific tariff is preferable to an ad valorem tariff, even though an ad valorem tariff generates more tariff revenue and all revenues are reallocated to the population. The initial trade regime is decisive for the effect on consumer welfare under the process of tariffication. In fact, in terms of consumers' utility, specific tariffication of a VER increases welfare while specific tariffication of a quota leaves welfare unaffected. On the other hand, ad valorem tariffication of a quota will reduce welfare while ad valorem tariffication of a VER is welfare neutral. Thus, tariffication relying on ad valorem tariffs has both an opportunity cost in terms of foregone consumer utility compared to tariffication relying on specific tariffs and might even be welfare reducing.

Economists agree that international trade is beneficial for the participating nations. Distortions to trade, such as tariffs or quotas, are harmful, yet they have been and are still widely used. Different barriers to trade have different impacts on the involved countries' welfare. Moreover different trade policy instruments have different visibilities, with a tariff being a clear and straightforward policy rule, while policies such as quotas or VERs are hard to quantify and hence blur the picture of the true level of protectionism. Recently GATT, and now its successor the World Trade Organisation (WTO), have initiated major breakthroughs in tackling protectionist measures of this kind by - among other things promoting widespread tariffication. The Final Act of the Uruguay Round states:

\footnotetext{
"Members shall not maintain, resort to, or revert to any measures of the kind which have been required to be converted into ordinary customs duties, ..."2

(Article 4, Agreement on Agriculture, Final Act of the Uruguay Round, 1994)
}

2. The footnote to this article explains: "These measures include quantitative import restrictions, variable import levies, minimum import prices, discretionary import licensing, non-tariff measures maintained through state-trading enterprises, voluntary export restraints, (...)." 
Tariffication is a process where non-tariff barriers such as quotas and VERs are converted into tariff equivalents in terms of import quantities, that is, tariffs that are set such as to result in the original trade volume. This process makes it easier to assess true levels of protectionism and creates a solid base for further negotiations and subsequent tariff reductions, and is thus in accordance with GATT (WTO) principles. Standard theory suggests that bilateral tariff-quota conversions are welfare neutral for perfectly competitive markets. However, domestic governments may benefit from tariffication because a tariff can extract rents in a situation with an initial give-away quota or VER. The importance and impact of tariffication in the recent GATT (WTO) rounds has been discussed among others by Ingco (1996) and Nguyen et al. (1993) (see also OECD (1996) and WTO (1998, chapter 3)). Further, Lawrence (1989) provides an assessment of the significance of tariffication for US trade policy. Finally, tariffication in agricultural markets has received particular attention. For example Larue et al. (1999) present a tariffication scenario for the Canadian dairy industry, and Carbaugh (1997) examines the impact of tariffication on the world trade in agricultural products.

Table 1 Average external tariff levels ${ }^{1}$ for major economies, percent

\begin{tabular}{lccccccc}
\hline & \multicolumn{2}{c}{ Food, beverages and tobacco } & & \multicolumn{3}{c}{ For all products } \\
\cline { 2 - 3 } \cline { 7 - 8 } & 1988 & 1993 & 1996 & & 1988 & 1993 & 1996 \\
\hline USA & $7.6^{2)}$ & 8.2 & 15.9 & & $4.4^{2)}$ & 4.7 & 5.2 \\
Japan & 15.6 & 17.5 & 18.9 & & 4.2 & 3.6 & 3.4 \\
EUR15 & 27.4 & 27.1 & 32.5 & & 8.2 & 8.4 & 7.7 \\
\hline
\end{tabular}

Note: 1. Average tariff levels are estimated by using production weights based on the destination countries' composition of value added. 2. 1989 value.

Source: OECD (1996), tables 1 and 2; OECD (1999) table 7.1, Authors' calculation.

The widespread tariffication trend can be detected in the average tariff levels of the major trading nations. Table 1 presents the developments in the external tariffs for three major economies. The effective tariff is measured by production weighted averages, i.e. based on the receiving countries' composition of production, and thus avoids the issue that the quantities demanded do react to the tariff. The data shows that on an overall level, tariffs 
are generally falling. But, for example, for the sector of food, beverages and tobacco, the mid 1990s see a rise in the average tariff level. The reason is tariffication.

The issue of tariff-quota equivalence, or rather the lack thereof, has received considerable attention in economics (see for example the work by Bhagwati (1965) and Helpman and Krugman (1989)). Nonetheless, there exist few models that explicitly study the case of tariffication, and to the best of our knowledge there is no formal approach that addresses the issue of tariffication for industries that feature monopolistic competition. There are, however, a number of contributions that relate to the present work. Kowalczyk and Skeath (1994) have shown that in a setting where a country faces one foreign monopolist, ad valorem tariffs are welfare superior to specific tariffs. The result is driven by the fact that the ad valorem tariff is superior in terms of revenue extraction. On the other hand, in line with our result, Das and Donnenfeld (1987) show that for a country facing a foreign monopolist that has a quality choice, the specific tariff generates the higher welfare. In a dynamic two-country game of setting optimal tariffs with retaliation, Lockwood and Wong (2000) show that the move from specific tariffs to ad valorem tariffs improves welfare in at least one country. Their model and in particular the mechanism driving it is very distinct from the present approach; what drives their result is the superiority of ad valorem tariffs in terms of revenue generation. As to the effects of tariffication Kaempfer and Marks (1994) present a model where the profitability of an exporting monopolist is affected by tariffication. They show that global efficiency - in the sense of purchasing from the lowest cost producer - may be reduced by the switch from a quota to a tariff. Again their setting is not one of monopolistic competition and increasing returns, rather, and contrary to the present model, producers vary as to their cost efficiency. Yet, the above contributions (as well as Helpman and Krugman (1989) when addressing non-equivalence of ad valorem to specific tariffs) deal with situations of monopoly or oligopoly but not with symmetric situations of monopolistic competition - the object of the present paper. The approach closest to the present paper is that of Gros (1987). Gros builds a two-country single industry model based on Krugman (1980) and studies a series of trade policies in this framework. His central results concern welfare effects of retaliation in tariff wars. However, Gros (1987) focusses primarily on ad valorem tariffs and does not address the welfare issue of tariffication. These issues are incorporated in the present model. 
This paper develops a general equilibrium model of monopolistic competition to examine tariffication. The formal approach builds on Krugman (1980). The present approach models two symmetric countries, with two industries, of which one is internationally traded, and treats tariffication explicitly. The tariff import-equivalent to an exogenously given and binding import restriction is calculated. We distinguish between an initial import restriction given by a quota and by a VER. It should be noted that this paper is not concerned with the emergence or rationale of the initial quota or VER but with its convergence into a tariff. The model further distinguishes between tariffication executed via a specific tariff and via an ad valorem tariff. First, it is found that there is a significant difference in the welfare impact between specific and ad valorem tariffication. Thus, - even with complete reallocation of all tariff revenues - a specific tariff generates more consumer utility than an ad valorem tariff. This result is driven by the larger number of variants in the traded sector in the case of a specific tariff. The specific tariff allows for more firms to exist, because industry profitability is higher. Or put differently, as a revenue extractor, the ad valorem tariff is more efficient than the specific tariff. This is what drives the results of models featuring monopoly or oligopoly market power (see Helpman and Krugman, 1989, chapter 4). However, due to this efficiency, industry profits are reduced, resulting in fewer firms. Second, we establish that the change in consumers' welfare under the process of tariffication depends crucially on the initial trade regime. If the import restriction initially is given by a VER (quota), then under the process of tariffication, welfare will be increased (remain unchanged) in case of a specific tariff and remain unchanged (be reduced) under an ad valorem tariff. In any case free trade dominates both the initial quota/VER situation as well as the tariffication situations in terms of consumer utility. Overall, the key result of the paper is that tariffication using ad valorem tariffs may have a potential opportunity cost in terms of the lost number of variants, compared to tariffication executed with a specific tariff.

The paper is structured as follows. Section 2 introduces the formal model. In section 3 we analyse the impact of the initial quota, VER and subsequent tariffication on quantities, prices and the number of variants in the traded sector. Hereby we distinguish between ad valorem tariffs and specific tariffs. Section 4 derives the spillover effects from the initial quota, VER and tariffication on the non-traded sector, namely those of the reallocated 
labour and spending power stemming from restrictions on the traded sector upon on the equilibrium in the unrestricted industry. Finally, section 5 presents the welfare results of the analysis. Section 6 concludes the paper.

\section{The Model}

We develop a setting of Chamberlinian monopolistic competition in the spirit of Spence (1976) and Dixit and Stiglitz (1977). The specific starting point for our model are its applications to international trade developed by Krugman (1980 and 1981). It is a wellknown result in trade theory that in a world with perfect competition, a quota and the import-equivalent tariff (specific or ad valorem) have the same impact on consumer prices in the importing country and that quota rents equal tariff revenue. Hence, tariffication would be a trivial policy change. However, if the importing country faces a foreign monopolist as the only supplier of a certain good, it is straightforward to show that the tariff revenue of a quota import-equivalent ad valorem tariff is higher than the tariff revenue of a quota import-equivalent specific tariff. Hence, tariffication is advantageous, and an ad valorem tariff is preferable to a specific tariff. The present model examines a monopolistic competition setting, i.e. a market condition between these two extreme forms, and finds that - from a consumer welfare perspective - specific tariffication is the preferred policy.

\section{Assumptions of the model}

It is assumed that the world consists of two symmetric countries, each with two industries. In both countries market conditions are described by monopolistic competition, increasing returns to scale in production and differentiated goods. Each industry has a large number of potential variants which enter symmetrically into demand. We assume that the first industry is a non-traded industry and that the other industry is a pure export industry, i.e. the second industry in the home country exports its entire output to the foreign country and vise versa. However, all our results can be extended to the case of actual intra-industry trade.

The present model adopts the utility function of Krugman (1981). However, for each industry we apply the functional form utilised in Krugman (1980). As the two countries are completely identical, we only show the specification for one of the countries throughout the 
analysis. All the individuals in the two countries are assumed to have the same utility function,

$$
U=\ln \sum_{i=1}^{N} c_{i}^{\theta}+\ln \sum_{j=1}^{\hat{N}} \hat{c}_{j}^{\theta}
$$

where $0<\theta<1$ and $c_{i}$ is consumption of the $i$ th variant of the foreign export industry and $\hat{c}_{j}$ is consumption of the $j$ th variant of the non-traded home industry. Due to symmetry between the two countries the imports of one country equal the exports of the other country and vise versa. $N$ and $\hat{N}$ define large numbers of potential variants in each industry. The number of variants actually produced $n$ and $\hat{n}$ are assumed to be large, although smaller than $N$ and $\hat{N}$.

For the moment we examine the properties of the export industry alone, bearing in mind that the free-trade equilibrium of the export industry is identical to the equilibrium of the non-traded industry. On the supply side we assume that there exists only one factor of production which is labour. All variants will be produced with the same cost function given by:

$$
l_{i}=\alpha+\beta x_{i} \quad i=1, \ldots n
$$

where $l_{i}$ is labour used in the production of the $i$ th variant in the traded industry and $x_{i}$ is output of that variant. This specification includes fixed costs $\alpha$ and constant marginal costs $\beta$ and hence average costs decline at a diminishing rate. This assumption ensures that each variant is produced by only one firm. Since by assumption one firm produces only one variant the number of variants equal the number of firms. Also since (2) implies that the labour requirements are identical for every variant, we can restrict our analysis to look at the market for one variant, since all other variants will behave identically. Hence, in the remainder of the paper the subscript $i$ can be omitted. Labour requirements are converted into nominal costs by multiplying (2) by the wage rate, $w$.

The market clearing condition demands that the output of each variant should be equal to 
the total consumption of all individuals in the economy of that variant. We will assume full equality between the number of workers and consumers. Hence, the market clearing condition implies that the consumption of a representative consumers times the labour force, $L$, must equal output, i.e.:

$$
x=L c
$$

\section{Equilibrium with free trade}

Finding equilibrium in this model follows the standard procedure assuming free entry and exit of firms, the zero-profit condition $\pi=p x-(\alpha+\beta x) w=0$ and labour market clearing at full employment (see e.g. Krugman 1980). The equilibrium turns out to be:

$$
\begin{aligned}
& x=\frac{\theta \alpha}{(1-\theta) \beta} \\
& p=\frac{\beta w}{\theta} \\
& n=\frac{L(1-\theta)}{2 \alpha}
\end{aligned}
$$

Since (4a-c) characterises the export industry in both countries, it also states the import conditions. In fact, $(4 \mathrm{a}-\mathrm{c})$ also states the equilibrium in the non-traded sector under free trade. Thus we have $\hat{x}=x, \hat{p}=p$ and $\hat{n}=n$.

\section{Defining a restriction on import volume}

In order to model tariffication we need to define an initial restriction on imports administered by either a quota or a VER. Noticing that the import volume of a country under free trade is given by $\chi=n x=\frac{L \theta}{2 \beta}$, a restriction on imports can accordingly be defined as:

$$
\bar{\chi}=\gamma \chi=\frac{\gamma L \theta}{2 \beta} \quad 0 \leq \gamma<1
$$


Thus, the parameter $\gamma$ measures how severe the initial import restriction is. In the analysis that follows, the different trade policy tools - tariffs (either an ad valorem or a specific tariff), quotas and VERs - are set such as to ensure that the resulting import volume is identical to the restricted import volume given in (5).

\section{Effects of Trade Policy on the Traded Sector}

This section analyses the effects of tariffication - i.e. the effects of applying specific and ad valorem tariffs that generate exactly the import volume given by the initial import restriction - on the market equilibrium in the traded industry. Section 4 will proceed by deriving the impact of these trade policies on the non-traded sector. The analysis commences by finding the market equilibrium under the initial import restriction. We distinguish between a restriction secured by a quota and a VER.

\section{Import restriction - binding quota}

The overall restriction on imports is given by (5). In this section we assume that the restriction is administered through a quota system, and that the quota is imposed by the home government via the fee, $F$. Paying the fee allows a foreign firm to export one unit of its product. Hence, the number of firms/variants in the export industry is endogenous. By adjusting $F$, the government controls the total amount of imports. Accordingly, the market clearing fee is set by the government such that the total amount of imports matches the import constraint. ${ }^{3}$ Throughout the paper it is assumed that all revenue that accrues to the government - either, as in this section, the quota fee or, as in the following sections, the tariff revenues - is completely redistributed to the consumers.

Individuals, by maximizing the utility function given in (1), will attempt to use the fraction $1 / 2$ of their income on imports. The profit of a firm producing one variant is given by

\footnotetext{
3. Alternatively, the same allocation can be obtained by a competitive bidding quota mechanism where the desired number of quotas are auctioned off; i.e a system where a foreign firm bids the maximum price it is willing to pay for a fixed export share. The two methods are interchangeable as long as the zero profit assumption is maintained.
} 
$\pi^{q}=\left(p^{\tau}-F\right) x^{\tau}-\left(\alpha+\beta x^{\tau}\right) w$. Defining the fee in real terms by $f=\frac{F}{w}$, the profit function can be written as $\pi^{q}=p^{\tau} x^{\tau}-\left(\alpha+(\beta+f) x^{\tau}\right) w$. Hence, this quota system with payment of a fee can be interpreted as an increase in marginal cost. Free entry and exit ensure that firms compete industry profits down to zero. The market equilibrium under this quota system where the overall import volume is restricted to $\bar{\chi}$ is characterized by:

$$
\begin{aligned}
& x^{q}=\frac{\theta \alpha}{(1-\theta)(\beta+f)} \\
& p^{q}=\frac{(\beta+f) w}{\theta} \\
& n^{q}=\frac{\gamma(1-\theta)}{2 \alpha} \frac{(\beta+f)}{\beta} \\
& f=\frac{\beta(1-\gamma)}{\gamma} \frac{2}{2-\theta}
\end{aligned}
$$

The fee $f$ is calculated from the condition that total consumer expenditure on the import industry must equal consumer expenditure on any industry, i.e. $p^{q} \bar{\chi}=\frac{w L+R^{q}}{2}$, where $R^{q}=f w \bar{\chi}$ is the revenue stemming from the quota fee which is redistributed to consumers. Plugging in the value for $f$ we get:

$$
\begin{aligned}
& x^{q}=\frac{\gamma(2-\theta)}{2-\theta \gamma} \frac{\theta \alpha}{(1-\theta) \beta}<x \\
& n^{q}=\frac{L(1-\theta)}{2 \alpha} \frac{2-\theta \gamma}{2-\theta}>n
\end{aligned}
$$

Thus, output per firm under a quota is less than under free trade. However, the number of firms in the traded sector has increased, even above the equilibrium number of firms under free trade. What motivates this increase? As can be seen from (6b) the cost connected with the quota fee is shifted onto prices with the factor $1 / \theta$. The intuition is that firms - since they act like monopolists - set their price as a mark-up over marginal costs. As shown above, the quota fee is in fact a marginal cost increase. Thus, in a sense firms overcompensate the 
fee, increasing profitability (their operating surplus) and accordingly creating entry into the industry. Also, since the revenues stemming from the fees are redistributed, consumers' spending power is maintained, thus eventually pushing the number of firms beyond the number of firms under free trade. However, as will be shown in section 5 , this increase in the number of firms is not a free lunch. The spending power stemming from the redistributed fee can be calculated:

$$
R^{q}=\theta(1-\gamma) \frac{L w}{2-\theta}
$$

Finally, due to the constraint of the initial import restriction the number of workers employed in the traded sector is reduced compared to the free trade case. In particular, the amount of labour reallocated from the export sector into the unrestricted non-traded sector is given by:

$$
\Delta L^{q}=\theta(1-\gamma) \frac{L}{2} \frac{1}{2-\theta}
$$

\section{Import restriction - binding VER}

In this section we analyse the situation where the import limit is administered through a VER. We assume that the foreign industry organises supply such as to limit total exports. The exporting firms compete on the market to get a share of the overall import volume given by the import restriction; i.e. some central authority in the foreign country allocates a share $1 / n^{v}$ to all the producers wanting to supply the market, subject to the constraint of the overall supply volume. Hence, the number of firms/variants in the export industry is still endogenous.

The profit of a firm producing a variant is given by $\pi^{v}=p^{v} x^{v}-\left(\alpha+\beta x^{v}\right) w$, where the quantity, however, is restricted by $x^{v}=\bar{\chi} / n^{v}$. Free entry and exit drive profits down to zero and the market equilibrium is derived as:

$$
x^{v}=\frac{\alpha \theta}{(1-\theta) \beta}
$$




$$
\begin{aligned}
& p^{v}=\frac{\beta w}{\theta} \\
& n^{v}=\frac{\chi(1-\theta)}{2 \alpha}=m
\end{aligned}
$$

Comparing a VER with free trade we see that prices and output of each variant are identical in the two situations. The only thing that differs is the number of variants, which is lower in the case of a VER, with $\gamma$ determining the reduction in the number of variants. The stricter the import constraint, the fewer variants will be available. In this setup a VER is in fact identical to a reduction in market size, that is, a reduction in $L$.

Also, less labour is employed in the traded sector under the VER compared to the free trade equilibrium. In fact, the amount of labour reallocated from the export sector into the unrestricted non-traded sector is given by

$$
\Delta L^{v}=(1-\gamma) \frac{L}{2}
$$

Furthermore, since prices have not risen, consumers do not spend the same amount of money on imported goods as in the unrestricted equilibrium. The amount of funds reallocated to other goods is:

$$
R^{v}=(1-\gamma) \frac{L w}{2}
$$

This spending power enters the non-traded sector, so that a restriction on the traded sector again has a spillover effect in the non-traded industry.

\section{Tariffication - ad valorem tariff}

We can now calculate the effects of an ad valorem tariff resulting in the same import volume as given by the initial restriction. However, any tariff will generate some tariff revenue. It is assumed that all revenue is redistributed completely to the consumers. An ad valorem tariff $t$ affects firms similarly to a tax. In particular, only the fraction $(1-t)$ of total sales revenue enters the exporting firm's profit function. Hence, the revenue part of the profit function changes, resulting in the profit function $\pi^{t}=(1-t) p^{t} x^{t}-\left(\alpha+\beta x^{t}\right) w$. 
Free entry and exit ensure that firms compete industry profits to zero. The equilibrium under an ad valorem tariff that generates the import volume $\bar{\chi}$ is characterised by:

$$
\begin{aligned}
& x^{t}=\frac{\theta \alpha}{(1-\theta) \beta}=x^{v} \\
& p^{t}=\frac{\beta w}{(1-t) \theta}>p^{v} \\
& n^{t}=\frac{\gamma L(1-\theta)}{2 \alpha}=n^{v} \\
& t=(1-\gamma) \frac{2}{2-\gamma}
\end{aligned}
$$

Thus tariffication utilising an ad valorem tariff results in the same number of variant (firms) and the same amount of output per firm as under the VER. However, what has changed is that prices have risen. In fact, what happens in the case of an ad valorem tariff, is that the foreign producers have handed the entire import tax over and on to the consumers. The tariff level can been derived from the condition - stemming from the maximisation of (1) - that total consumer expenditure on the import industry must equal consumer expenditure on any industry, i.e. $p^{t} \bar{\chi}=\frac{W L+R^{t}}{2}$, where $R^{t}=t p^{t} \bar{\chi}$ is the tariff revenue which is redistributed to consumers, increasing total spending power. Using the derived tariff level one can calculate:

$$
R^{t}=(1-\gamma) L w
$$

It should be noted that there are two opposing effects at work when imposing a tariff. An increase in the tariff level does decrease imports because of increased prices, but it also increases imports because of the increased spending power available to consumers. Since half of these funds are spent on non-traded products, however, tariff regulation of the import volume is possible. Note also that there is less labour employed in the traded sector (compared to the free trade equilibrium) and thus, the labour force employed in the nontraded sector is increased (compared to the free trade equilibrium) by the amount: 


$$
\Delta L^{t}=(1-\gamma) \frac{L}{2}
$$

In fact, the amount of reallocated labour is the same as under a VER.

\section{Tariffication - specific tariff}

We calculate the effects of a specific tariff resulting in the same import volume as given by the initial import restriction. Let $\mathrm{T}$ denote the specific tariff, then the profit function of a firm becomes $\pi^{\tau}=\left(p^{\tau}-\mathrm{T}\right) x^{\tau}-\left(\alpha+\beta x^{\tau}\right) w$. Defining the specific tariff in real terms by $\tau=\frac{T}{w}$ the profit function can be written as $\pi^{\tau}=p^{\tau} x^{\tau}-\left(\alpha+(\beta+\tau) x^{\tau}\right) w$. Hence, when a specific tariff is imposed it enters the exporting firms profit function like an increase in marginal cost. Note, that this case is in fact identical to the quota case with $T=F$ and $\tau=f$. This result is in line with the findings in Gros (1987). Accordingly, (6a-d) and (7ab) also states the equilibrium under specific tariffication; i.e. $x^{\tau}=x^{q}, p^{\tau}=p^{q}$, $n^{\tau}=n^{q}, \tau=f, R^{\tau}=R^{q}$ and $\Delta L^{\tau}=\Delta L^{q}$. Thus, tariffication utilising a specific tariff results in more firms selling at higher prices, but with less output per firm, compared to the situation under the VER. Furthermore, the increased expenditures on fixed costs $\alpha$ (due to more variants) resulted in higher employment in the traded sector, hence fewer workers will transfer into the non-traded industries, compared to the VER and compared to ad valorem tariffication.

What drives the difference between the specific and the ad valorem tariff is the interaction of industry and firm profitability. As the ad valorem tariff is simply passed along to consumers (via the price increase), the individual firm's profitability (operating surplus) remains unchanged, hence their maximisation results in the same firm-level output volume as before. However, since prices have risen, industry profitability suffers and there is less room for firm entry before industry profits turn zero. In the specific tariff case, firms' profitability is in fact increased, i.e. the operating surplus is increased. Since a constant fixed cost $\alpha w$ has to be exactly offset for a firm to enter the industry, then with a larger operating surplus smaller output runs suffice to achieve breakeven. Hence, industry profitability is also larger than in the ad valorem case, allowing more firms to enter before 
industry profits turn zero. So as a revenue extractor, the ad valorem tariff is more efficient than the specific tariff. ${ }^{4}$ However, due to this efficiency, industry profits and firms' operating surpluses are lower than under a specific tariff, resulting in fewer firms. To verify this point consider industry profitability $\Pi^{s}$, which we represented by the profits that a single firm would achieve under the above derived prices, tariffs and quantity $\bar{\chi}$, and operating surplus $\sigma^{s}$, given by the difference between marginal revenue and marginal cost. In particular it turns out that: $\Pi^{t}=\frac{(1-\theta) w \gamma L}{2}-\alpha w<\frac{2-\theta \gamma}{2 \gamma-\theta \gamma} \frac{(1-\theta) w \gamma L}{2}-\alpha w=\Pi^{\tau} \quad$ and $\sigma^{\mathrm{t}}=\frac{(1-\theta) \beta \mathrm{w}}{\theta}<\frac{(1-\theta)(\beta+\tau) \mathrm{w}}{\theta}=\sigma^{\tau}$.

\section{Effects of Trade Policy on the Non-traded Sector}

In this section we analyse the impact on the non-traded sector through the spillovers from the labour market. The reallocated labour from the constrained export industry will move to the non-traded industry. Intuitively, when more workers are employed in the non-traded sector, the result will be a larger number of variants available. Besides, the trade regime has an effect on the amount of labour reallocated to the non-traded sector and hence plays a crucial role. Recall from section 3 that the total spending power equals the wage earnings plus the revenue stemming from either the quota or the tariff, where in the case of the VER there is no revenue to be reallocated, but consumers have more than half their funds available for consumption of non-traded goods. In particular, since we solve the model in general equilibrium, the total spending power ensures that the extra variants produced in the non-traded sector will be demanded.

Formally, the new labour supply for the non-traded industries, $\hat{L}^{s}$, can be written as:

$$
\hat{L}^{s}=\frac{1}{2} L+\left(\Delta L^{s}\right) \quad s=q, v, \tau, t
$$

Recall that a ' $\wedge$ ' in connection with any parameter refers to the non-traded industries. $\frac{1}{2} L$ is the labour supply available for the non-traded industry in the free trade case. $\Delta L^{s}$ is the

4. This is in line with findings that e.g. Lookwood and Wong (2000) and Kowalczyk and Skeath (1994) have made in very different settings. 
amount of reallocated labour from the constraint export industry, where the actual amount depends on which trade instrument is used (quota, VER, specific or ad valorem tariff). The increase in available labour does not influence the equilibrium output and price of the individual firm in the non-traded industry and hence output and price is equal to $\hat{x}$ and $\hat{p}$ given in (4a and b) respectively. In fact, this reallocation is identical to an increase in market size, and thus only influences the equilibrium number of variants, and hence also total industry output. The equilibrium number of variants, $\hat{n}^{s}$, is found by using the labour market clearing condition for the non-traded industry given by:

$$
\hat{L}^{s}=(\alpha+\beta \hat{x}) \hat{n}^{s} \quad s=q, v, \tau, t
$$

Combining (10) and (11) and inserting $\Delta L^{s}$ found in the analysis in section 3, we find the equilibrium number of variants in the non-traded industry for the three possible trade instruments respectively:

$$
\begin{aligned}
& \hat{n}^{q}=\hat{n}^{\tau}=\frac{2-\theta \gamma}{2-\theta} n \\
& \hat{n}^{v}=\hat{n}^{t}=(2-\gamma) n
\end{aligned}
$$

From (12) it immediately follows that $\hat{n}^{q}, \hat{n}^{v}, \hat{n}^{t}, \hat{n}^{\tau}>n$ and $\hat{n}^{q}=\hat{n}^{\tau}<\hat{n}^{v}=\hat{n}^{t}$, i.e. the number of firms in the non-traded sector are larger under the VER and in the case of ad valorem tariffication compared to the quota and specific tariffication. This last inequality is caused by the fact that the amount of reallocated labour to the non-traded industry is lowest under the quota and the specific tariff.

\section{Welfare Results}

In this section we will analyse the effects of tariffication on consumer welfare. The comparison of the different trade policy regimes is complicated by the spillover effects from the restricted sector into the unrestricted (non-traded) sector. In section 4 we have shown that reallocated labour and spending power from the constrained export sector will, when entering the non-tradable sector, result in a larger number of available variants, thus increasing utility. However, intuitively it is clear that since a loss of utility from the constrained traded sector has to be compensated by increases in utility from the non-traded 
sector, and since we assume diminishing marginal utility, the utility gain in the non-traded sector is insufficient to compensate consumers up to the free trade utility level. In fact we demonstrate that if tariff revenues are completely reallocated to the population, then consumers will be indifferent between a VER type import restriction and the importequivalent ad valorem tariff, while they will strictly prefer the import-equivalent specific tariff which turns out to be identical to the quota type import restriction. Thus, from a consumer's point of view, specific tariffs are the preferable means of tariffication for industries that feature monopolistic competition.

Given the initial import restriction - secured by either a quota or a VER - the two forms of tariffication and their respective impact on the traded and non-traded sector, it is possible to calculate the gains and losses in welfare. In particular, since all spending power is with consumers, we know that all that is produced will actually be consumed, hence the relevant values for $n$ and $x$ can be plugged right into the utility function, and one can compare the utility levels in the different scenarios. Inserting equations (4a-c) into (1) gives utility $U$ under free trade:

$$
U=2 \ln \left(\frac{L}{2}(1-\theta)^{1-\theta} \alpha^{\theta-1} \theta^{\theta} \beta^{-\theta}\right)
$$

Utility depends positively on the size of the economy and falls with an increase of the fixed cost $\alpha$ and variable $\operatorname{cost} \beta$.

Using (1), ( 6)-(8) and (9) utility under the four different trade regimes is given by:

$$
\begin{aligned}
& U^{q}=\ln \left(\frac{2-\theta \gamma}{2-\theta} \Omega\right)+\ln \left(\gamma^{\theta}\left(\frac{2-\theta \gamma}{2-\theta}\right)^{1-\theta} \Omega\right) \\
& U^{v}=\ln ((2-\gamma) \Omega)+\ln (\gamma \Omega) \\
& U^{t}=\ln ((2-\gamma) \Omega)+\ln (\gamma \Omega) \\
& U^{\tau}=\ln \left(\frac{2-\theta \gamma}{2-\theta} \Omega\right)+\ln \left(\gamma^{\theta}\left(\frac{2-\theta \gamma}{2-\theta}\right)^{1-\theta} \Omega\right)
\end{aligned}
$$


where $\Omega=\frac{L}{2}(1-\theta)^{1-\theta} \alpha^{\theta-1} \theta^{\theta} \beta^{-\theta}$, and $q, v, \tau$ and $t$ denote the scenarios of the quota, the VER, tariffication via a specific tariff, and tariffication via an ad valorem tariff respectively. The first term of each expression states the utility stemming from the consumption of nontraded products, while the second term measures utility from the consumption of imports. The following result immediately follows from (14a-d):

Proposition 1. Given a certain import restriction, consumers are indifferent between a quota and specific tariffication; and consumers are indifferent between a VER and ad valorem tariffication. In particular,

$$
U^{q}=U^{\tau} \text { and } U^{v}=U^{t}
$$

Utility under the specific tariff is identical to utility under the quota as both the maximization problem of the firms and the revenue gain is the same in the two cases. The ad valorem tariff is identical to utility under the VER, even though the reallocated tariff revenues $R^{t}$ have been larger than the retained funds $R^{v}$ that occurred under the VER. Still the two scenarios arrive at the same utility level. This is because the price level in the tariffication case has also increased $\left(p^{t}>p^{v}\right)$, and in particular because under tariffication, consumers actually do use half of their total funds on all sectors, while in the VER case, a smaller share of income was used on the import sector. In fact, the higher spending power under ad valorem tariffication is exactly offset by the higher price level in the traded sector. From (14a-d) it is possible to deduce the following welfare ranking:

Proposition 2. Given a certain import restriction, consumers strictly prefer specific tariffication to ad valorem tariffication. Yet, free trade is preferred to any level of the import restriction. In particular,

$$
U>U^{\tau}=U^{q}>U^{v}=U^{t}
$$

Proof. See appendix 1 and 2.

Total consumer utility is larger under a specific tariff than under an ad valorem tariff (given the same trade restriction), yet both tariff regimes are dominated by free trade. The 
superiority of the specific tariff compared to the ad valorem tariff stems from the fact that under a specific tariff (and in fact also under a quota) more profits remain in the traded sector, allowing more firms to exist. Since consumers love variety, this policy generates the higher welfare, even though the total import restriction is the same.

Given the results in proposition 1 and 2 one can draw conclusions on the impact of tariffication. Consumers prefer specific tariffication to ad valorem tariffication. However, whether the tariffication process is at all desirable from the consumers' point of view depends on the nature of the initial import restriction. If the initial import restriction is given by a VER, then tariffication will at least be welfare neutral (using ad valorem tariffs) and at best be welfare improving (using specific tariffs). On the other hand, if the initial import restriction is given by a quota, then tariffication will at best be welfare neutral (using specific tariffs) and at worst be welfare reducing (using ad valorem tariffs). It follows that when the initial trade barrier (to be converted into a tariff) is constructed from a mix of quotas and VERs, then specific tariffication will be welfare increasing, while ad valorem tariffication will be welfare reducing.

\section{Conclusion}

The 1990s have seen widespread tariffication for the members of GATT and later WTO. This process of converting quotas and VERs into their tariff import-equivalents has been endorsed by governments and economists alike. The present paper argues that, in a world of monopolistic competition, tariffication has a significant effect on welfare, beyond the simple revenue generating argument, and that the method of tariffication - ad valorem versus specific tariff - feature non-trivial differences in terms of consumer welfare. Furthermore, the change in the consumers' welfare under tariffication depends crucially on the nature of the initial trade regime - quota or VER. What drives the results of this paper is the number of variants in the export industry.

The model of the paper builds on Krugman (1980). In a symmetric, two country, general equilibrium model, the case of bilateral tariffication for a binding quota and a VER can be addressed for specific functional forms. The main results of this analysis are that, under the assumption of monopolistic competition, quotas/VERs and their import-equivalent tariffs 
can result in different effects in terms of prices, the number of firms/product variants and the output per firm. In particular, in the traded goods sector a binding quota (VER) results in higher (the same) prices, less (the same) output per firm, and an even higher (lower) number of firms than under free trade. Enforcing the same amount of total imports via an ad valorem tariff results in the same number of firms as the binding VER (hence, also the same output per firm), however prices are higher than in the VER case. Enforcing the same amount of total imports via a specific tariff results in exactly the same equilibrium as under the binding quota. Further, all four trade policy instruments have spillover effects on the non-traded sector. In particular, an ad valorem tariff restriction in the import sector will result in a larger increase of the number of produced variants in the non-traded sector than a specific tariff.

In terms of the effect on consumers' utility, it is established that utility under specific tariffication - though less than under free trade - is higher than under ad valorem tariffication. Furthermore, utility under ad valorem tariffication is identical to utility under an initial VER, whereas utility under specific tariffication is identical to utility under an initial quota. This result is obtained under an assumption of complete redistribution of all tariff revenues.

This paper has thus established that when evaluating the welfare impact of tariffication for industries that feature monopolistic competition, it is important both to distinguish between the tariff tool used in tariffication and the initial trade regime. Thus our central finding is that an unduly reliance on ad valorem tariffication under the rules of WTO has both an opportunity cost in terms of the lost number of product variants and might even be welfare reducing. 


\section{Acknowledgements}

This paper benefited from the comments of Michael Pflüger, Pascalis Raimondos-Møller and Jan Rose Sørensen. The authors would also like to thank the participants at the Nordic International Trade Seminar, 2001 and at the 51st International Atlantic Economic Conference, 2001. The authors are responsible for any remaining errors. 


\section{Appendix}

1. Proof that $U^{q}, U^{v}, U^{\tau}, U^{t}<U$.

Consumer utility under trade protection, but with full reallocation of tariff revenues, is less than utility under free trade. Recall from (15) that $U^{\tau}=U^{q}$ and $U^{t}=U^{v}$.

\subsection{Proof that $U^{t}<U$.}

From (14d) it follows that $U^{t}=U+\ln (2-\gamma)+\ln \gamma$. Hence, one has to show that:

$$
K^{t}=\ln (2-\gamma)+\ln \gamma<0 .
$$

It follows from (A1) that $\operatorname{Lim}_{\gamma \rightarrow 0} K^{t}=-\infty$ and $\underset{\gamma \rightarrow 1}{\operatorname{Lim}} K^{t}=0$. Since $\frac{\partial K^{t}}{\partial \gamma}=\frac{2-2 \gamma}{(2-\gamma) \gamma}>0$, $\hat{K}^{t}$ is monotone increasing in $\gamma$ for all $0<\gamma<1$, (A1) is fulfilled.

\subsection{Proof that $U^{\tau}<U$.}

From $(14 \mathrm{c})$ it follows that $U^{\tau}=U+(2-\theta) \ln \left(\frac{2-\theta \gamma}{2-\theta}\right)+\theta \ln \gamma$. Hence, one has to show that:

$K^{\tau}=(2-\theta) \ln \left(\frac{2-\theta \gamma}{2-\theta}\right)+\theta \ln \gamma<0$

It follows from(A2) that $\operatorname{Lim}_{\gamma \rightarrow 0} K^{\tau}=-\infty$ and $\underset{\gamma \rightarrow 1}{\operatorname{Lim} K^{\tau}}=0$. Since $\frac{\partial K^{\tau}}{\partial \gamma}=\theta\left(\frac{2(1-\gamma)}{(2-\theta \gamma) \gamma}\right)>0$,

$K^{\tau}$ is monotone increasing in $\gamma$ for all $0<\gamma<1$, (A2) is fulfilled.I

2. Proof that $U^{\tau}>U^{t}$. Tariffication with a specific tariff and complete reallocation of all tariff revenues gives higher consumer utility than tariffication with an ad valorem tariff. 
From (14c and d) it follows that:

$U^{\tau}>U^{t}$

$\Uparrow$

$(2-\theta) \ln \left(\frac{2-\theta \gamma}{2-\theta}\right)+\theta \ln \gamma>\ln (2-\gamma)+\ln \gamma$

Define the function:

$$
F(z)=(2-z) \ln \left(\frac{2-z \gamma}{2-z}\right)+z \ln \gamma
$$

If $F(z)$ is monotone decreasing in $z$, then $b>a$ implies $F(a)>F(b)$, and hence (A3) is fulfilled as $1>\theta$.

From (A4) it follows that

$$
\frac{\partial F}{\partial z}=\ln \left(\frac{\gamma(2-z)}{2-z \gamma}\right)+\frac{2(1-\gamma)}{2-z \gamma}
$$

One has to show that for a given $z$ (A5) is negative for all $\gamma, 0<\gamma<1$. It follows from (A5) that

$$
\operatorname{Lim}_{\gamma \rightarrow 0} \frac{\partial F}{\partial z}=-\infty \text { and } \operatorname{Lim}_{\gamma \rightarrow 1} \frac{\partial F}{\partial z}=0
$$

and since

$$
\frac{\partial\left(\frac{\partial F}{\partial z}\right)}{\partial \gamma}=\frac{4(1-\gamma)}{\gamma(2-z \gamma)^{2}}>0
$$

(A5) is monotone increasing in $\gamma$ for all $z$ and thus negative in the relevant parameter intervals. 


\section{References}

Anderson, J., 1997. Revenue Neutral Trade Reform with Many Households, Quotas and Tariffs, NBER Working Paper, No. 6181.

Bhagwati, J., 1965. On the Equivalence of Tariffs and Quotas, in: Baldwin, R. et al. (Eds.) Trade, Growth and the Balance of Payments. Rand McNally, Chicago.

Carbaugh, R., 1997. Tariff-Rate Quotas and the Uruguay Round. Journal of Economics, Vol 23 (2), 1--10.

Das, S., Donnenfeld,S., 1987. Trade Policy and its Impact on Quality of Imports: A Welfare Analysis. Journal of International Economics, Vol 23 (1/2), 77--95.

Dixit, A.K., Stiglitz, J.E., 1977. Monopolistic Competition and Optimum Product Diversity. American Economic Review, Vol. 67, No.3, 297--308.

Gros, D., 1987. Protectionism in a Framework with Intra-industry Trade: Tariffs, Quotas, Retaliation, and Welfare Losses. International Monetary Fund Staff Papers, Vol. 34 (1), 86-114 .

Helpman, E., Krugman, P., 1989. Trade Policy and Market Structure. MIT Press.

Ingco, M., 1996. Tariffication in the Uruguay Round: How Much Liberalisation?. World Economy, Vol. 19 (4), 425--46.

Kaempfer, W., Stephen, M., 1994. The Possibility of Inefficient Liberalisation through Tariffication. Review of International Economics, Vol.2 (2), 123--130.

Kowalczyk, C., Skeath, S.E., 1994. Pareto Ranking Optimal Tariffs under Foreign Monopoly. Economic Letters, Vol. 45, 355-359. 
Krugman, P., 1980. Scale Economies, Product Differentiation, and the Pattern of Trade. American Economic Review, Vol. 70 (5), 950--959.

Krugman, P., 1981. Intraindustry Specialisation and the Gains from Trade. Journal of Political Economy, Vol.89 (5), 959--973.

Larue, B., Veeman, M., Fulton, M., 1999. Protection, Price Discrimination and Inefficient trade: The Case for Real Tariffication. Canadian Journal of Agricultural Economics, Vol 47 (5), 77--89.

Lawrence, R., 1989. Protection: Is There a Better Way?. American Economic Review, Vol. 79 (2), 118--126.

Lockwood, B., Wong, K.-Y., 2000. Specific and Ad Valorem Tariffs are Not Equivalent in Trade Wars. Journal of International Economics, Vol. 52, 183--195.

Nguyen, T., Perroni, C., Wigle, R., 1993. An Evaluation of the Draft Final Act of the Uruguay Round. The Economic Journal, Vol. 103, 1540--1549.

OECD (1996), Indicators of Tariff and Non-tariff Trade Barriers. Paris.

OECD, 1999. OECD Economic Outlook No. 65. Paris.

Spence, M. 1976. Product Selection, Fixed Costs and Monopolistic Competition. Review of Economic Studies, 217--235.

WTO, 1994. Final Act of the Uruguay Round. World Trade Organization, Geneva.

WTO, 1998. Annual Report 1998. World Trade Organization, Geneva. 